Relations industrielles

Industrial Relations

\title{
L'indexation des salaires dans les pays industrialisés à économie de marché, Genève, Bureau international du travail, 1978, 67 pp.
}

\section{Claude Rondeau}

Volume 34, numéro 3, 1979

URI : https://id.erudit.org/iderudit/029000ar

DOI : https://doi.org/10.7202/029000ar

Aller au sommaire du numéro

Éditeur(s)

Département des relations industrielles de l'Université Laval

ISSN

0034-379X (imprimé)

1703-8138 (numérique)

Découvrir la revue

Citer ce compte rendu

Rondeau, C. (1979). Compte rendu de [L'indexation des salaires dans les pays industrialisés à économie de marché, Genève, Bureau international du travail, 1978, 67 pp.] Relations industrielles / Industrial Relations, 34(3), 623-623.

https://doi.org/10.7202/029000ar

Tous droits réservés (C Département des relations industrielles de l'Université Laval, 1979
Ce document est protégé par la loi sur le droit d'auteur. L’utilisation des services d'Érudit (y compris la reproduction) est assujettie à sa politique d'utilisation que vous pouvez consulter en ligne.

https://apropos.erudit.org/fr/usagers/politique-dutilisation/ 
the administration of contemporary collective bargaining legislation. At a time when trade unions are complaining that labour boards are too legalistic and formal, it is surprising to see the argument made for a return to the more formal procedure of a court. The author, moreover, appears to underestimate the importance of the representative members from labour and management in the decisionmaking of the labour boards. The board members, who bring to the Board extensive labour relations experience, do have a significant influence on labour board decisions an influence that would not be present in a labour court. The author, however, does recognize this problem, proposing that administrative matters be left to a tri-partite board that might be advisory to the court, which would deal with more fundamental matters. Such a structure, though, would be far too cumbersome to process cases with the expedition required in labour relations. One can only conclude that the author does not recognize the lesson of the first Labour Court - that a purely judicial structure is not well suited for the administration of labour relations laws.

Don CARTER

Queen's University

L'indexation des salaires dans les pays industrialisés à économie de marché, Genève, Bureau international du travail, 1978, $67 \mathrm{pp}$.

Cette monographie publiée par le Bureau international du travail comprend trois parties. Le premier chapitre traite des modalités techniques de l'indexation des salaires à un indice du coût de la vie. Les chapitres II à $\mathrm{V}$ décrivent la situation des différents pays industrialisés selon que l'indexation est généralisée, limitée, presqu'inexistante ou qu'elle constitue un élément d'une politique publique de revenus. Enfin, un dernier chapitre présente une synthèse des attitudes patronales, syndicales et gouvernementales face à l'indexation des salaires dans les pays étudiés.
Au chapitre I, après une brève discussion des notions de rémunération et de coût de la vie, on trouve un examen assez complet des méthodes d'indexation des salaires: variable à ajuster, périodicité des ajustements, indice utilisé, période de référence, forme et montant d'ajustement. Il est un problème assez aigu qui n'est pas mentionné, celui de l'intégration de l'indemnité de vie chère au salaire régulier.

Les chapitres suivants contiennent des renseignements intéressants mais assez généraux sur l'utilisation de l'indexation des salaires au coût de la vie dans les conventions collectives de plusieurs pays. La catégorisation des expériences nationales est révélatrice de l'influence exercée par certains facteurs sur le phénomène de l'indexation: le contexte historique, le degré de centralisation de la négociation, le degré d'intervention étatique dans la distribution des revenus, la maturité du régime de relations de travail, etc... Bien que le document s'en tienne au niveau descriptif, de nombreuses hypothèses de recherche sautent aux yeux du lecteur attentif et intéressé à la théorie des sytèmes de relations industrielles.

Bref, il s'agit d'une brochure utile, qui devrait intéresser surtout le profane en la matière, désireux de se renseigner sur le phénomène de l'indexation des salaires au coût de la vie au plan international.

Claude RONDEAU

Unịversité Laval

Using the Social Sciences, by Albert Cherns, London, Routledge and Kegan Paul, 1979, $502 \mathrm{pp}$.

Social sciences may contribute to policy making by providing practitioners with basic concepts and theories about man and society, delivering data and devising technical solutions to problems. According to Cherns, "by increasing the policy-maker's knowledge and understanding of the system in which he is operating and the characteristics and poten- 